\title{
O PRINCÍPIO DA CONCENTRAÇÃO E A AQUISIÇÃO A NON DOMINO. REFLEXÕES SOBRE A LEI 13.097/2015. EVOLUÇÃO HISTÓRICA E DIREITO COMPARADO
}

\author{
THE PRINCIPLE OF CONCENTRATION AND ACQUISITION TO NON DOMINO. \\ REFLECTIONS ON LAW 13.097 / 2015. HISTORICAL DEVELOPMENTS AND \\ COMPARED LAW
}

\author{
Fábio Caldas de Araújo ${ }^{1}$ \\ Celso Hiroshi Iocohama ${ }^{2}$
}

\section{Resumo}

O artigo tem por escopo demonstrar os efeitos da Lei 13.097/2015 sobre o registro de imóveis e a aquisição a non domino. Neste sentido, relata-se que a presunção de propriedade em favor daquele que constava como titular junto ao registro de imóveis, originariamente, estabelecido pelo art. 859 do Código Civil de 1916 e confirmado pela orientação do art. 1245 do Código Civil de 2002 sofre substancial alteração pela Lei 13.097/2015 que garante, ao terceiro de boafé, proteção integral em face dos vícios decorrentes da evicção. Por fim, conclui-se que a mudança de posicionamento legislativo provoca uma alteração radical no modelo romano que influenciou toda a formação do sistema brasileiro, especialmente pela influência das Ordenações Afonsinas, Manuelinas e Filipinas. A proteção conferida ao terceiro vai além da tímida proteção conferida pelo art. 1242 do Código Civil brasileiro, tornando efetiva a proteção de situações jurídicas estabilizadas pela boa-fé objetiva perante o registro. A recente alteração exigiu uma análise comparativa com o modelo alemão, em vista da presunção absoluta conferida por aquele sistema ao registro, o que possibilita traçar um caminho de orientação para a jurisprudência brasileira.

\footnotetext{
${ }^{1}$ Pós-Doutor pela Universidade de Lisboa. Doutor e Mestre em Direito Processual Civil pela PUC-SP. Professor Titular da Universidade Paranaense. Professor da Escola da Magistratura do Estado do Paraná e dos cursos de Especialização da UEL, PUC-SP e da Fundação do Ministério Público de Cuiabá. Membro do Núcleo de Pesquisas Científicas da Escola da Magistratura do Paraná. Juiz de Direito no Estado do Paraná. E-mail: gesetzgeber@uol.com.br

${ }_{2}^{2}$ Advogado. Mestre em Direito pela UEL. Doutor em Direito pela PUC-SP. Doutor em Educação pela USP. Professor da Graduação e do Programa de Mestrado em Direito Processual e Cidadania da Universidade Paranaense - UNIPAR.
} 
Palavras-chave: boa-fé; usucapião; registros públicos; segurança jurídica; terceiro de boa-fé.

\begin{abstract}
The presente article has to demonstrate the effects of Law 13.097/ 2015 on real estate registration and non domino acquisition. In this sense, it is reported that the presumption of ownership in favor of the one that appeared as holder with the real estate registry, originally, established by art. 859 of the Civil Code of 1916 and confirmed by the orientation of art. 1245 of the Civil Code of 2002 is substantially amended by Law 13.097 / 2015, which guarantees, the third party in good faith, full protection against the defects arising from eviction. Finally, it is concluded that the change of legislative position causes a radical change in the Roman model that influenced the whole formation of the Brazilian system, especially, by the influence of the Afonsinas, Manuelinas and Philippine Ordinations. The protection afforded to the third party goes beyond the timid protection afforded by art. 1242 of the Brazilian Civil Code, making effective the protection of legal situations stabilized by objective good faith before registration. The recent change required a comparative analysis with the German model, in view of the absolute presumption granted by that system to the registry, which makes it possible to draw a guide to Brazilian jurisprudence.
\end{abstract}

Keywords: Bona fides, adverse possession, public legal records, Legal certainty, Third party in good faith.

\title{
1 CONSIDERAÇÕES PRELIMINARES. EVOLUÇÃO DO DIREITO BRASILEIRO E INFLUÊNCIA DO DIREITO COMPARADO, ATÉ SE CHEGAR À LEI 13.097/2015
}

De um modo geral, o fenômeno da globalização trouxe um novo desafio aos sistemas jurídicos vigentes. ${ }^{3}$ Muito embora estejamos distantes do modelo romano, sua influência foi marcante ao longo do desenvolvimento de todos os sistemas jurídicos no que tange à forte proteção conferida ao direito de propriedade. Sob a perspectiva da História do Direito, o registro corresponde a uma criação recente e que esta diretamente ligada à segurança jurídica e ao

\footnotetext{
${ }^{3}$ A velocidade da informação e das transformações em todos os ramos científicos conta com uma interessante abordagem de Gilles Lipovetsky e Sébastien Charles, sobre a pós-modernidade e a hipermodernidade, in Os Tempos Hipermodernos, p. 24 e ss.
} 
fortalecimento da posição jurídica do terceiro de boa-fé. Este ponto é crucial para o tema em debate, pois toda a análise sobre a posição do terceiro que adquire bem a non domino deve ser enfocada sobre o prisma da boa-fé.

A tensão entre o proprietário e o terceiro adquirente de boa-fé trazia solução prevalente para o titular do direito de propriedade, mesmo no tratamento dos bens móveis, o que demonstra a força do direito de propriedade no período romano e sua influência marcante perante o direito brasileiro. ${ }^{4}$ A boa-fé, analisada unicamente sob o prisma subjetivo, não tinha o condão de gerar situação jurídica autônoma e protetiva, exceto pela configuração da usucapio. ${ }^{5}$

Por regra, o direito de propriedade gozava de proteção especial pela reivindicatio, o que justificou o nascimento dos interdicta. Em muitas situações o pretor percebeu que a disputa não estava ligada à titularidade da propriedade, mas sobre a sua ocupação provisória e temporária. Os interditos possessórios e a proibição da exceptio domini (art. 557 CPC/2015) nascem da aguda percepção prática do pretor romano. ${ }^{6}$ A posse nasce do reconhecimento de que nem todas as disputas sobre o ius utendi, fruendi e abutendi decorrem de um conflito sobre a titularidade dominial. Daí a importância aguda de autores modernos evidenciarem a posse como um fenômeno jurídico desvinculado da propriedade. ${ }^{7}$

O sistema moderno exigiu o fortalecimento do sistema de transmissão dos bens móveis e imóveis. Os bens móveis, especialmente após o florescimento do comércio medieval, propiciaram a transmissão da propriedade pela posse de boa-fé. O fenômeno ficou conhecido no direito inglês por meio das feiras de open market e repercutiu na França pela formação das regras costumeiras de Bourjon. O direito brasileiro absorveu esta evolução na codificação de

\footnotetext{
${ }^{4}$ A regra de Bourjon (en fait de meubles, la possession vaut titre) insculpida no célebre art. 2279 do Código Civil francês (atual art. 2276) não gerou influência no Código Civil brasileiro de 1916. O art. 622 do Código Civil brasileiro revogado espelha com perfeição o posicionamento do direito brasileiro às ordenações e ao direito romano. Vide a redação da primeira parte: "Feita por quem não seja proprietário, a tradição não alheia a propriedade". Sobre a regra de Bourjon, Fenet, Recueil Complet des Travaux Préparatoires du Code Civil, t. XIII, pp. 09-123.

${ }^{5}$ Sobre o ponto e o desenvolvimento histórico da usucapião ordinária, Fabio Caldas de Araújo, Usucapião, p. 73, com especial referência ao período pós-clássico.

${ }^{6}$ A sobrevivência atual da exceptio domini, na configuração atual do art. 557 do CPC/2015, é discutível. Dois são os pontos de reflexão. O primeiro relativo à inexistência de registro de imóveis, cujo lento nascimento é decorrente da evolução germânica do período medieval (vide infra). Segundo, pelo fato de a teoria possessória ainda não estar desenvolvida a ponto de ser visualizada a posse causal e sem causa, bem como a diferença entre a posse indireta e direta. Sobre a posse indireta, vide a excelente monografia de José Paulo Cavalcanti, A Falsa Posse Indireta, em especial p. 23 e ss., Recife, 1990, fac-símile.

${ }^{7}$ Destaca-se o refinado tratamento de Hernandes Gil, La Funcion Social de la Posesion, p. 21 e ss.
} 
2002, por meio do art. 1.268, uma versão temperada do dispositivo francês, mas que colocou nosso ordenamento à frente de diplomas como o Código Civil português. ${ }^{8}$

Quanto aos bens imóveis, o sistema registral floresce no modelo germânico, no século XVI, cuja evolução foi barrada pelas dificuldades de formação do Estado Alemão, em que o processo de unificação viria a ocorrer somente no século XIX. ${ }^{9} \mathrm{Na}$ França, o sistema registral surge no período revolucionário, mas com função diversa e atrelada à garantia do crédito. Os empréstimos concedidos com o período da revolução industrial exigiam garantias. A garantia de execução do crédito sobre o bem imóvel somente alcançaria o bem pela sequela real, desde que formalizado o registro. ${ }^{10}$

O Brasil sofreria o influxo destes dois ordenamentos na construção de um modelo que pudesse conferir segurança jurídica em um território de dimensões continentais. A segurança não era apenas um atributo econômico, mas de garantia e integridade da própria nação, ou seja, do Estado Brasileiro.

O modelo brasileiro tem inspiração no sistema alemão, mas não se pode afirmar que há uma simples transposição. Essa falsa impressão provocou um tórrido debate em torno da aplicação do art. 859 do Código Civil brasileiro de 1916. ${ }^{11}$ Seria impensável que um país de dimensão continental e que contava, e ainda conta, com uma imensa desorganização em seu sistema cadastral pudesse ter a ousadia de reclamar a presunção absoluta do registro quando existisse eventual defeito na transmissão, com base na fé pública imanente ao registro imobiliário. ${ }^{12} \mathrm{O}$ ponto nodal da questão seria a incidência, ou não, de solução correspondente à do $\$ 892$ do BGB (Bürgerliches Gesetzbuch, o Código Civil alemão), que não havia sido inserido explicitamente no Código Civil brasileiro. Como o art. 859 do Código Civil brasileiro de 1916 refletia o $\$ 891$ do BGB, que retratava mera regra de presunção no campo processual, abriu-se o debate sobre o real alcance do dispositivo para o registro no direito brasileiro. $\mathrm{O}$ art. 859 do Código Civil brasileiro de 1916 modificou a antiga tradição inaugurada pelo art. $8 .^{\circ}, \S^{\circ}{ }^{\circ}$

\footnotetext{
${ }^{8} \mathrm{O}$ regime jurídico português revela, pela leitura do funcionamento do sistema quanto aos bens móveis, o rigor e proteção ao direito de proprietário. Prevalece a defesa da posição do verus dominus quando contraposta à posição do terceiro adquirente, ainda que de boa-fé. No direito português, Menezes Cordeiro, Direitos Reais, p. 287.

${ }^{9}$ Hans-Armin Weirich, Grundstückrecht, pp. 1-6.

${ }^{10}$ Huc, Commentaire Théorique \& Pratique du Code Civil, t. XIV, pp. 7-12.

${ }^{11}$ Soriano Neto, Publicidade Material do Registro Immobiliário, p. 11.

${ }^{12}$ Fato que não passou desapercebido pela doutrina que se defrontou sobre o tema, após a promulgação do Código Civil brasileiro de 1916: "As condições especiaes da nossa propriedade territorial e o natural retardamento na marcha evolutiva de nossas instituições de direito privado (a das instituições de direito publico vem, ao contrario, se processando por saltos incríveis, que nos levam além da realidade nacional) jamais permittiriam assentassemos o nosso direito immobiliário nos moldes aperfeicoadissimos do systema germanico" (Soriano Neto, Publicidade Material do Registro Immobiliário, p. 13).
} 
da Lei Hipotecária n ${ }^{\circ} 1237$ de 1864 , porque estabelece a presunção da propriedade em favor daquele que constar como titular junto ao registro de imóveis.

Nem todos os atos judiciais constavam como necessários ao registro (art. 532, I Código Civil brasileiro de 1916) e, com a promulgação do Código Civil brasileiro de 1916, alterações legislativas, realizadas por leis extravagantes, foram essenciais para adaptar paulatinamente nossa legislação. O Decreto $\mathrm{n}^{\circ} 4827$ de 1924 criou a inscrição preventiva e a possibilidade de registro de situações jurídicas ad rem. ${ }^{13}$ Este Decreto teve caráter geral e sistematizou, conforme seu art. $1^{\circ}$, os diversos registros referentes aos atos da vida civil das pessoas físicas e jurídicas, títulos e documentos, registro dos imóveis e da propriedade intelectual. Segue-se importante alteração proporcionada pelo Decreto n ${ }^{\circ} 18.542$ de 1928 , no qual o sistema registral passa a incorporar o princípio da continuidade como corolário da segurança quanto à cadeia de transmissão (arts. 234 e 237, I e parágrafo único). ${ }^{14}$

Nos anos seguintes, deve-se mencionar o Decreto $\mathrm{n}^{\circ} 4.857$ de 1939 que não trouxe qualquer alteração substancial, e que, pensou-se então, deveria sujeitar-se a modificações. Nessa época nosso extenso teritório já reclamava um cadastro unificado que contasse com um livro fundiário para a individuação da matrícula de cada imóvel com todo o seu histórico. A proposição foi alvo de dois projetos elaborados por Afrânio de Carvalho. O primeiro finalizado nos idos de 1947 quando houve uma tentativa de instituir o cadastro de imóvel pelo surgimento da aerofotografia. ${ }^{15}$ Seria impensável concluir pela possibilidade de cadastramento de todos os imóveis no Brasil sem um sistema moderno que permitisse a organização do sistema tabular. As discussões foram intensas, mas sem o resultado esperado. As intensas discussões que pairaram sobre a modificação do Decreto $n^{\circ} 4.857$ de 1939 geraram a elaboração de nova

\footnotetext{
${ }^{13}$ Affonso Dionysio Gama, Os Registros Publicos do Código Civil (Lei no 4827 de 7 de fevereiro de 1924 e Reg. 18542 de 24 de dezembro de 1928), pp. 18-20.

${ }^{14}$ Affonso Dionysio Gama, Os Registros Publicos do Código Civil (Lei no 4827 de 7 de fevereiro de 1924 e Reg. 18542 de 24 de dezembro de 1928), p. 119. O princípio da continuidade foi inserido pelo art. 234: "Em qualquer caso não se poderá fazer a transcripção ou inscripção sem prévio registro do título anterior, salvo se este não estivesse obrigado a registro, segundo o direito então vigente de modo a assegurar a continuidade do registro de cada prédio, entendendo-se por disponibilidade a faculdade de registrar alienações ou onerações dependentes, assim, da transcripção anterior" (destacamos).

15 Atualmente a evolução tecnológica permite que a medição seja realizada por satélite, por meio de georeferenciamento, utilizando-se o Sistema Geodésico Brasileiro, nos termos do art. 176, $\$ 3^{\circ}$ da Lei 6015/73, cuja alteração é proveniente da Lei 10267/01. Trata-se de uma revolução no sistema registral brasileiro e orientado para as áreas rurais. Os novos atos de transmissão, desmemembramento, ou qualquer ato que afete a continuidade da matrícula sujeitam-se ao geo-referenciamento. O Decreto $n^{\circ} 4449 / 02$, em seu art. 10, estabeleceu prazo para a adaptação das propriedades rurais, em virtude do seu tamanho às exigências da nova forma de confirmação do cadastro real do imóvel. A grande vantagem do georeferenciamento sobre os demais sistemas de medição é o fato de que o imóvel é mensurado pelos seus polígonos, mas considerando todas as irregularidades do terreno por meio de cálculos matemáticos.
} 
legislação por meio do Decreto-lei $n^{\circ} 1000$ de 1969. Esta norma teve curta vigência e foi eliminada pela aprovação da atual Lei de Registros Públicos, a Lei no 6015 de 31 de dezembro de 1973. Inúmeras alterações foram implementadas em seu texto com o fim de aperfeiçoá-lo, já que tem uma característica peculiar, pois disciplina toda a atividade registrária. No sistema lusitano, ao contrário, o registro de imóveis encontra disciplina em lei própria para o tratamento da transmissão dos bens móveis e imóveis (Dl. 224/1984, Código de Registro Predial português).

As alterações ultimadas pela Lei $n^{\circ}$ 6.015/1973 foram efetivadas perante o espírito do Código Civil brasileiro de 1916. A observação quanto à evolução dos textos legislativos revela uma aproximação cada vez maior com o sistema alemão. ${ }^{16}$ A dinâmica dos atos negociais exige a segurança como condição basilar para a celebração de negócios jurídicos que envolvam bens imóveis. Curiosamente, o direito brasileiro assumiu uma condição peculiar na profusão de uma jurisprudência defensiva da posse pelo fato de o instituto imprimir a visibilidade do domínio e afetar um número expressivo de pessoas. Essa proteção da posse pode ser visualizada como uma resposta à rigidez legislativa quanto ao tratamento do terceiro de boa-fé.

Somente por meio da Lei $\mathrm{n}^{\circ} 13.097 / 2015$, mais de cem anos após a promulgação do Código Civil brasileiro de 1916, é que o terceiro irá encontrar acomodação protetiva no sistema brasileiro por meio do registro, como resposta de fortalecimento de sua posição no tráfego negocial. Por meio da lei registral obtempera-se-á a força do art. 1247, parágrafo único do Código Civil brasileiro de 2002.

A Lei 13.097/2015 traz a necessidade de uma releitura dos arts. 1245 e 1247, parágrafo único do Código Civil brasileiro de 2002, na medida em que o art. 54, parágrafo único da Lei 13.097/2015 permite a consolidação da posição do terceiro, desde que de boa-fé, em face dos vícios provocados pela evicção. Essa compreensão exige a digressão prévia sobre pontos essenciais, atinentes ao papel da boa-fé em nosso sistema, bem como a busca incessante pela segurança jurídica agora respaldada pela fé pública registral. ${ }^{17}$

\section{A BOA-FÉ E A SEGURANÇA JURíDICA NO TRÁFEgo NEGOCIAL (RECHTSVERKEHR)}

\footnotetext{
${ }^{16}$ Afrânio de Carvalho, Registros de Imóveis, p. 28.

17 Marinho Debinski Kern, A lei 13.097/2015 adotou o princípio da fé pública registral?, p. 15-58, v. 78 RT, 2015.
} 
A sociedade moderna, especialmente após a revolução industrial, passou a conhecer o consumo em escala. O impacto e o crescimento comercial refletiriam, inevitavelmente, no sistema jurídico. Além do aperfeiçoamento dos títulos de crédito, as sociedades comerciais passaram a adotar modelos complexos que obrigam à regulação de práticas comerciais e processuais em leis extravagantes, alterando a topologia codificada que marcou a sedimentação do direito positivo no século XIX.

Nesse panorama deve ser agregada a recepção da boa-fé objetiva como elemento essencial para a segurança das relações jurídicas, cujo desenvolvimento se deve ao gênio alemão. ${ }^{18}$ Muito embora já recepcionada pelo BGB na Alemanha, em 1896, com seus antecedentes no HGB (Handelsgesetzbuch, o Código Mercantil alemão), é possível afirmar que o tema foi praticamente desconhecido da doutrina brasileira. ${ }^{19}$ Apenas no final do século XX, com a preocupação voltada para a reforma do Código Civil brasileiro de 1916, que culminou com o diploma atual do ano de 2002, a doutrina procurou maior profundidade quanto ao importantíssimo tema, especialmente com apoio na doutrina portuguesa. ${ }^{20}$

A questão da boa-fé objetiva avultou no sistema brasileiro pelas peculiaridades que informam o sistema de proteção da propriedade imobiliária e mobiliária. O Brasil sofreu a influência predominante do direito francês por largo período no campo material e processual. Isso explica, de certo modo, as dificuldades de construção do sistema tabular em nosso regime jurídico, o qual seria vital, em vista da debilidade e desorganização na formação dos títulos dominiais. As dimensões continentais do território brasileiro exigiriam uma forma racional de organização do cadastro imobiliário e o regime tabular assumiria importância destacada no modelo brasileiro como elemento de auxílio na estabilidade da proteção e segurança das relações jurídicas. Por sua vez, percebem-se as dificuldades existentes no direito português para uma proteção efetiva do terceiro de boa-fé em relação aos bens móveis, em vista da inexistência de recepção da regra de Bourjon pela qual a posse vale título (en fait de meubles la possession

\footnotetext{
${ }^{18}$ Rudolf Meyer, Bona fides und lex mercatoria in der europäischen Rechtstradition, p. 36 e ss.

${ }^{19}$ Mesmo Pontes de Miranda, maior tratadista brasileiro, não realizou a percepção nítida quanto à distinção entre os regimes de incidência da boa-fé subjetiva ( guter Glaube) e da boa-fé objetiva (Treu und Glauben). Sobre a boafé possessória deve ser consultado, Pontes de Miranda, Tratado de Direito Privado, t. X, §1078, p. 126.

${ }^{20}$ Menezes Cordeiro, Da Boa-fé no Direito Civil, passim. Esta obra representa um marco divisório do Direito moderno quanto ao tema. Quem realizar a leitura integral desse denso trabalho tomará contato com a análise profunda e o desenvolvimento histórico minucioso sobre a boa-fé, com pesquisa inigualável nas fontes e que permite compreender temas até então obscuros, como a distinção entre bona fides e aequitas, bem como a importância de Aristóteles quanto à laicização do direito e o desapego dos conceitos metafísicos de Platão. Não há paralelo sobre o tema, nesta profundidade, mesmo na doutrina alemã.
} 
vau titre). Isso não eliminou a possibilidade de proteção do terceiro, na aquisição da propriedade imóvel ou móvel sujeita registro, no sistema lusitano, pela interessante figura prevista no art. 291 do Código Civil português e pela proteção específica do Código de Registro Predial português por meio de seus arts. $5^{\circ}$ e 17.

O direito brasileiro nunca contou com este sistema peculiar de proteção para os bens imóveis. O Código Civil brasileiro previa uma proteção ao terceiro de boa-fé por meio da usucapião abreviada especial, conforme previsão insculpida pelo art. 1242, parágrafo único, do Código Civil de 2002. Somente no ano de 2015 é possível antever, na legislação brasileira, uma modificação singular, ao se prever a possibilidade de proteção do terceiro de boa-fé por meio do registro, inclusive contra a evicção, conforme dicção do art. 54, parágrafo único da Lei $\mathrm{n}^{\circ}$ $13.097 / 1995 .^{21}$

\section{A BOA-FÉ REGISTRAL E O PRINCÍPIO DA CONCENTRAÇÃo}

A contraposição entre a situação possessória e a registral propicia um enfraquecimento natural da proteção conferida pela publicidade cadastral no sistema brasileiro. Muito embora a posse exerça indiscutível papel social, a realidade brasileira é absolutamente diversa dos sistemas europeus, que serviram de inspiração ao nosso modelo.

Ao se resguardar a posição do terceiro de boa-fé, protege-se, em última análise, uma situação possessória que é suficiente para a defesa do seu titular. Esta situação não é estranha em nosso sistema. A proteção construída pelas súmulas 84 e 308 do STJ não desmentem esta afirmação, pois permitem que o possuidor possa paralisar a pretensão executorial ou dominial, desde que demonstrada a posse de boa-fé.

\footnotetext{
${ }^{21}$ O sistema registral brasileiro é regido pela Lei $\mathrm{n}^{\circ}$ 6015/73 com suas subsequentes alterações. As duas alterações mais importantes e significativas desde sua implantação, no que toca à proteção da boa-fé, reside na adoção do modelo espanhol do patrimônio de afetação pela Lei $n^{\circ}$ 10.931/2004 e na inserção do princípio da concentração por meio da Lei $\mathrm{n}^{\mathbf{0}} 13.097 / 2015$. Por meio da primeira alteração procurou-se imunizar a matrícula registral para que incorporadoras e construtoras não pudessem gravar os terrenos que seriam utilizados para a construção de edifícios, com o fim de não prejudicar terceiros que realizassem a aquisição de unidades por meio de contratos preliminares. A segunda alteração de impacto veio por meio da Lei n ${ }^{\circ}$ 13.097/2015 que positivou o princípio da concentração em seu art. 54. No sistema brasileiro, até então, somente as ações reais e reipersecutórias poderiam ser objeto de registro com o fim de proteger terceiros de boa-fé. Todavia, com o fim de permitir proteção integral, toda e qualquer constrição judicial (arresto, sequestro, indisponibilidade) poderá (rectius, deverá) ser averbada para prevenir eventual insolvabilidade do devedor perante terceiros (art. 54, III e IV). E mais, o art. 54, parágrafo único é de leitura cristalina: "Não poderão ser opostas situações jurídicas não constantes da matrícula no Registro de Imóveis, inclusive para fins de evicção, ao terceiro de boa-fé que adquirir ou receber em garantia direitos reais sobre o imóvel, ressalvados o disposto nos arts. 129 e 130 da Lei ${ }^{\circ} 11.101$, de 9 de fevereiro de 2005, e as hipóteses de aquisição e extinção da propriedade que independam de registro de título de imóvel' (grifo nosso).
} 
Neste ponto, percebe-se que a Lei 13.097/2015 apresenta parâmetros para que a boa-fé possa ser materializada e para que possa fornecer proteção para todos aqueles que dependem do registro. A concentração determinada pelo art. 54 e seus incisos opera autêntico fortalecimento da boa-fé objetiva processual. A necessidade de registro de todos os atos que possam prejudicar a garantia do credor, assim como a transmissão da propriedade, deve constar da matrícula, sob pena de reconhecimento da fraude à execução ou da fraude contra credores.

A proteção contra a fraude processual tem como objetivo imediato garantir a efetividade do processo como instrumento público de realização do direito material e como objeto mediato a satisfação material do credor. Na seara processual, a fraude visa a coibir toda a alienação ou oneração dolosa que vise a frustrar a relação executiva. Os efeitos provocados pela sua configuração são de ineficácia processual (art. 792, §1º do CPC/2015). A ineficácia demonstra que a declaração de vontade permanencerá íntegra no plano da existência e da validade e apenas não surtirá eficácia, em relação ao prejudicado.

$\mathrm{O}$ art. 792 do CPC/2015 revela tipo enunciativo, uma vez que o inciso $\mathrm{V}$ determina que não estão vedadas outras hipóteses de fraude previstas em leis especiais. O dispositivo deve ser conjugado, obrigatoriamente, com o art. 54 da Lei n 13.097 de 19 de janeiro de 2015. Essa importante lei, de acordo com explanação retro, mudou o panorama do direito brasileiro ao permitir uma nova forma de aquisição originária da propriedade para os bens imóveis, qual seja, a aquisição pelo registro por parte do terceiro de boa-fé (art. 54, parágrafo único, da referida lei). Essa lei representa uma revolução ao criar a propriedade imóvel a non domino, independentemente da usucapião. Na análise da penhora, o art. 54 da Lei no 13.097/2015 também representa um divisor de águas, especialmente porque ilumina a interpretação dos incisos do art. 792 do CPC/2015 que representam as principais hipóteses de fraude à execução.

Muito embora a posse tenha sido estabilizada por meio de transmissão negocial, se o ato ocorrer após ter sido averbada ação de natureza real ou reipersecutória, de nada importará o compromisso de compra e venda e quitado. Neste caso, o adquirente não poderá alegar a existência de boa-fé que é fundamental para a concretização da súmula 84 do STJ. Denota-se a importância do registro como meio de publicidade e marco legal para a concretização da boafé subjetiva do terceiro adquirente.

O art. 792, II do CPC/2015, de modo claro, estabelece a necessidade do registro da ação de execução, nos mesmos termos do art. 54, II da Lei no 13.097/2015. A publicidade da execução impede qualquer transferência posterior da posse. Não estará configurada a boa-fé, uma vez que o terceiro conhece a existência de um título executivo judicial ou extrajudicial apto a deflagrar o processo de expropriação contra o devedor. Logo, será inviável qualquer 
estabilização da posse. A questão apenas assume contorno diferenciado quando a transmissão for anterior, o que leva a uma prevalência da posse anteriormente transmitida, ainda que se trate de uma execução fiscal. ${ }^{22}$ A negligência do possuidor apenas afetará a sucumbência eme eventual ação de embargos de terceiro (súmula 303 do STJ).

Todos os gravames e ônus que pesarem sobre a matrícula antes da transmissão da posse impedem a aplicação da súmula 84 do STJ. O princípio da concentração, que tem base no art. 54 da lei no 13.097/2015, não permite outra interpretação. A hipoteca judiciária decorrente de uma sentença civil condenatória é um exemplo (art. 792, III do CPC/2015). A sentença em que se confirma o an debeatur permite a hipoteca judiciária (art. 495, § $1^{\circ}$, I do CPC). A própria prenotação da ação executiva, na matrícula do bem, impede qualquer alienação posterior, nos termos do art. 799, IX do CPC/2015, sob pena de fraude e ineficácia do ato de transmissão.

$\mathrm{O}$ art. 792, IV, do CPC/2015, a nosso ver, revela um dos dispositivos de maior vagueza para fins de configuração da fraude, pois determina que esta se caracterizará quando ao tempo da alienação ou da oneração tramitava contra o devedor ação capaz de reduzi-lo à insolvência. O dispositivo não dispensa o registro da ação, o que é reafirmado pelo art. 54 , IV da Lei ${ }^{\circ}$ 13.097/2015: “averbação, mediante decisão judicial, da existência de outro tipo de ação cujo resultados ou responsabilidade patrimonial possam reduzir seu proprietário à insolvência".

Este dispositivo rompe com uma tradição do Direito brasileiro que permitia apenas o registro de ações reais ou reipersecutórias. Uma leitura atualizada da função e natureza do registro público não peossibilitaria outra solução. As medidas judiciais de indisponibilidade de bens concedidas em ações de improbidade administrativa (art. $7^{\circ}$ da Lei $\mathrm{n}^{\mathbf{o}}$ 8429/92) demonstram a existência de medida constritiva, mesmo quando ausente título executivo, ou pretensão de natureza real. O que autoriza a inscrição da ação é possibilidade de redução do devedor à insolvabilidade, até o final do processo por atitude de dissipação do patrimônio.

A redação do art. 54, IV da Lei 13.097/2015 é de acerto duvidoso. Afinal, não é a ação que levará o réu à insolvência, mas a atitude reprovável do devedor que efetiva a alienação, a

\footnotetext{
${ }^{22}$ STJ, "É assente na jurisprudência desta Corte de Justiça que a celebração de compromisso de compra e venda, ainda que não tenha sido levado a registro no Cartório de Registro de Imóveis, constitui meio hábil a impossibilitar a constrição do bem imóvel, discutido em execução fiscal, e impede a caracterização de fraude à execução, aplicando-se o disposto no enunciado da Súmula 84/STJ: "É admissível a oposição de embargos de terceiro fundados em alegação de posse advinda do compromisso de compra e venda de imóvel, ainda que desprovido do registro." (REsp 974062/RS, Rel. Ministra Denise Arruda, 1a T., julgado em 20/9/2007, DJ 5/11/2007, p. 244$) 3$. "A jurisprudência desta Corte, consolidada com a edição da Súmula 375/STJ, orienta que sem o registro da penhora sobre o imóvel ou prova da má-fé do adquirente, não há que se falar em fraude à execução." (AgRg no AREsp 48.147/RN, Rel. Ministro Sidnei Beneti, $3^{\mathrm{a}}$ T., julgado em 7/2/2012, DJe 24/2/2012) Agravo regimental improvido".(AgRg no AREsp 449.622/RS, Rel. Ministro Humberto Martins, $2^{\text {a }}$ T., julgado em 11/03/2014, DJe $18 / 03 / 2014)$.
} 
título oneroso ou gratuito, com o fim de dissipar o patrimônio e impeder o resultado útil da demanda. A posse e a transferência de bens de modo fraudulento também exigirá análise sobre a licitude quando suscitado o incidente de desconsideração da personalidade juridica, na modalidade direta ou indireta. ${ }^{23}$ A prenotação decorrente do art. 54, IV nascerá por determinação judicial e não conterá, necessariamente, valor determinado. O exemplo supra da hipoteca judiciária revela um exemplo claro. A sentença poderá ter determinado o pagamento de uma indenização por ato ilícito, mas cujo valor dependerá de liquidação por arbitramento, ante a necessidade de prova pericial (art. 509, I do CPC/2015).

\section{A PROTEÇÃO AO TERCEIRO DE BOA-FÉ NO DIREITO BRASILEIRO E A LEI $\mathbf{N}^{\circ} \mathbf{1 3 . 0 9 7 / 2 0 1 5}$}

A Lei 13.097/2015 inseriu modificações importantes no sistema registral. Nela destacase a previsão do princípio da concentração e da aquisição a non domino pelo terceiro de boafé. As alterações sistemáticas provocadas pela redação do art. 54, I a IV e parágrafo único da mencionada lei são, sem dúvida, uma das maiores ocorridas no sistema civil desde a promulgação do Código Civil brasileiro de 2002. A mudança ainda é praticamente desconhecida quanto à sua real importância e seus efeitos. Sua leitura exige uma nova interpretação dos arts. 1245 e 1247, parágrafo único do Código Civil brasileiro de 2002. Por meio dos arts. 54 e 55 da Lei $\mathrm{n}^{\circ}$ 13.097/2015 o direito brasileiro ruma, nitidamente, para uma proteção similar à fornecida pelo sistema alemão, conforme leitura do $§ 892$ do BGB.

O art. 54, parágrafo único, da Lei n ${ }^{\circ}$ 13.097/2015 e o art. 1245 do Código Civil brasileiro permitem que os dispositivos do art. 291 do Código Civil Português e do art. 17 do Código de Registro Predial português possam iluminar a construção do modelo brasileiro. Nosso sistema passa a conferir uma proteção que ultrapassa a figura do art. 1242, parágrafo único do Código Civil brasileiro.

O fato mais curioso é que a proteção conferida pelo art. 54, parágrafo único pode ser estudada, quanto à origem legislativa, em comparação com o art. 2652, n. ${ }^{\circ} 6$ do Código Civil Italiano. ${ }^{24}$ Este dispositivo tem elementos de influência sobre o nascimento do art. 291 do

\footnotetext{
${ }^{23}$ Sobre a origem e desenvolvimento, Menezes Cordeiro, O levantamento da personalidade colectiva, p. 103. No direito brasileiro, Fabio Caldas de Araújo, Intervenção de Terceiros, p. 322.

${ }^{24}$ In verbis: " le domande dirette a far dichiarare la nullità [1422] o a far pronunziare l'annullamento [1425, 1445] di atti soggetti a trascrizione e le domande dirette a impugnare la validità della trascrizione [2665, 2675].
} 
Código Civil português e do art. 1242, parágrafo único do Código Civil brasileiro. E por mais que a aquisição a non domino pela via do registro esteja configurada pelo art. 54, parágrafo único da Lei 13.097/2015, não foram estabelecidos requisitos específicos para a consumação da posição do terceiro de boa-fé, com base no registro. Entendemos que este parâmetro há de ser fixado na construção do standard a ser obedecido no caso concreto. Os elementos apontados pelo direito alemão quanto à construção da boa-fé para fins do $\$ 932$ do BGB representam certamente uma fonte de orientação para a leitura sobre a boa-fé do terceiro adquirente.

$\mathrm{O}$ art. 2652, n. ${ }^{\circ} 6$ do Código Civil italiano, em sua primeira leitura, parece harmonizarse com a modalidade da usucapião abreviada do art. 1242, parágrafo único do Código Civil brasileiro. Todavia, esta aproximação é equivocada. No direito italiano, o dispositivo já havia sido criticado quanto à sua forma de redação, porque foi copiado da legislação austríaca. A solução adotada pelo direito brasileiro, até antes da Lei $n^{\circ} 13.097 / 2015$, foi linear e forte. Ao inserir a previsão do art. 1242, parágrafo único no Código Civil brasileiro de 2002, o legislador criou um tipo diferenciado para fins de usucapião. E com sua alocação na usucapião é possível afirmar que o direito brasileiro havia assumido uma posição ainda mais radical que a do ordenamento português. Esta conclusão advém da conexão entre o art. 1245 e o art. 1247, parágrafo único do Código Civil brasileiro.

Esta questão assumiria maior complexidade. À primeira vista, havia uma tendência natural de transportar para o art. 1242, parágrafo único do Código Civil brasileiro, a figura do art. 2562, no 6 do Código Civil italiano. Esta transposição deveria ser evitada. É possível que seja colhida uma tênue influência quanto ao prazo e escopo de proteção do terceiro, porém, o dispositivo do art. 2652, $\mathrm{n}^{\circ} 6$ do CC italiano nasce de uma necessidade de proteção específica da publicidade originada pelo ato de transcrição. Até o advento do art. 54, parágrafo único da Lei 13.097/2015 esta proteção era inexistente no direito brasileiro. Até então, o art. 1245 e 1247, parágrafo único do Código Civil brasileiro não permitiam proteção ao terceiro de boa-fé pela existência do registro. A evicção permitiria o ajuizamento de ação de nulidade do registro cumulando-a com pretensão de reivindicação do bem imóvel.

\footnotetext{
Se la domanda è trascritta dopo cinque anni dalla data della trascrizione dell'atto impugnato, la sentenza che l'accoglie non pregiudica i diritti acquistati a qualunque titolo dai terzi di buona fede in base a un atto trascritto o iscritto anteriormente alla trascrizione della domanda. Se però la domanda è diretta a far pronunziare l'annullamento per una causa diversa dall'incapacità legale la sentenza che l'accoglie non pregiudica i diritti acquistati dai terzi di buona fede in base a un atto trascritto o iscritto anteriormente alla trascrizione della domanda, anche se questa è stata trascritta prima che siano decorsi cinque anni dalla data della trascrizione dell'atto impugnato, purché in questo caso i terzi abbiano acquistato a titolo oneroso [1445; disp. att. 227].
} 
$\mathrm{O}$ art. 2652, n 6 do CC italiano nunca revelou uma hipótese de usucapião. Aliás, no próprio direito italiano existe a previsão específica de usucapião ordinária, como modalidade de usucapião abreviada (usucapione abbreviata). ${ }^{25}$ Isso exige que as figuras sejam extremadas para que eventual confusão seja evitada. Esta diferenciação é perfeitamente possível no Direito italiano e deve se transportada para o ordenamento brasileiro. A explicação é simples. No direito brasileiro não havia qualquer previsão, seja na Lei de Registros Públicos ou mesmo no Código Civil brasileiro, de proteção para o terceiro que confiou no registro, isso é, inexistência de mecanismos de proteção para o terceiro com base na verdade registral. Logo, nada mais natural que toda a proteção fosse canalizada para a usucapião abreviada, pois o registro de uma alienação onerosa e com boa-fé seriam causas para diminuição sensível do prazo da usucapião. Esta situação era paradoxal, pois apesar do sistema brasileiro trabalhar com um registro público de natureza constitutiva, a proteção concedida ao terceiro de boa-fé era débil.

O sistema italiano tem um mecanismo diferenciado pelo fato de regular de modo minucioso, em seu Código Civil, as disposições referentes à transcrição da propriedade para fins de publicidade (arts. 2643 a 2696 do CC italiano). O art. 2652, nº 6 do referido Código não retrata hipótese de usucapião. O dispositivo prevê prazo específico para o registro da ação de impugnação ao registro, no prazo de 5 anos, do título proveniente do alienante. Não há menção nenhuma no dispositivo de qualquer combinação envolvendo posse e tempo. O terceiro de boa-fé consolida sua posição jurídica de modo absoluto, não pelo exercício de posse mansa e pacífica, mas por contar com um título transcrito, de modo oneroso, cuja causa primária não tenha sido atacada em até 5 anos. A aproximação entre a figura da aquisição a non domino imediata prevista pelo art. 2652, nº., e a usucapião tabular ordinária, foi alvo de confusão na própria doutrina italiana. ${ }^{26}$

Essa confusão não é mais possível sequer no ordenamento brasileiro. A Lei $\mathrm{n}^{\circ}$ 13.097/2015 muda radicalmente o cenário da aquisição da propriedade no direito brasileiro. Se até o ano de 2015 o direito brasileiro não contava com qualquer dispositivo para a proteção efetiva do terceiro de boa-fé, que confiasse na publicidade do registro de imóveis, o cenário agora é diverso. O direito brasileiro, por meio do parágrafo único do art. 54 da Lei $\mathrm{n}^{\circ}$ 13.097/2015 mira, de modo claro, para o ordenamento alemão, com opção expressa pela proteção ao terceiro de boa-fé na circulação econômica dos bens imóveis. A proteção conferida

\footnotetext{
${ }^{25}$ C. Massimo Bianca, Diritto Civile, v. 6, p. 820.

${ }^{26}$ Como confessa Mengoni, Gli Acquisti a non domino, p. 302. Segundo o mesmo autor, fala-se em uma função sanante da publicidade, ainda que relativa.
} 
pela usucapião ordinária especial do art. 1242, parágrafo único, do Código Civil deixa de ser a única alternativa viável para a consolidação da posição jurídica do terceiro.

\section{O SISTEMA DE REGISTRO BRASILEIRO: DA PRESUNÇÃO RELATIVA PARA A ABSOLUTA}

O sistema brasileiro sempre foi causal e o registro nunca ofereceu proteção absoluta. Não existia qualquer correlação do direito brasileiro com a aplicação do §892 BGB. Se alguma discussão ainda foi possível perante o art. 859 do Código Civil brasileiro de 1916, o diploma civil de 2002 sequer repetiu a regra de presunção do registro. A presunção relativa ainda poderia ser intuída pela combinação dos arts. 1245 e 1247, caput e parágrafo único do Código Civil brasileiro. Nossa legislação sempre aderiu ao modelo romano de proteção aos bens imóveis e o Código Civil brasileiro nunca propiciou uma luz de aproximação com o sistema alemão, em vista da inexistência de proteção absoluta conferida pelo registro. ${ }^{27}$

Além de exigir a combinação do título e do modo como meio de consumar a aquisição da propriedade, o direito brasileiro sempre permitiu que o registro pudesse ser invalidado, mesmo após o registro do ato de aquisição. Não havia proteção similar à oferecida pelo direito português, ou mesmo pelo direito italiano, e muito menos, na plenitude conferida pelo direito alemão.

A pretensão de anulação ou nulidade voltada para o negócio jurídico que embasa o registro permitiria o pedido de nulidade do título e a cumulação com a reivindicação da propriedade. A redação do art. 1247, caput do Código Civil brasileiro não permitiria outra interpretação: "Se o teor do registro não exprimir a verdade, poderá o interessado reclamar que se retifique ou anule".

Como o registro poderia ser anulado ou cancelado, o sistema brasileiro deveria prever algum mecanismo para sanar o vício do registro quando presente um terceiro de boa-fé. A solução adotada pelo direito brasileiro era radical. E nesse aspecto muito mais severa do que a previsão legal do art. 291 do Código Civil português, que permite um diálogo das fontes (Dialog der Quellen) com os arts. $5^{\circ}$ e $17^{\circ}$ do Código de Registro Predial daquele país. No direito

\footnotetext{
${ }^{27}$ Na vigência do Código Civil brasileiro de 1916, o STF foi chamado a se manifestar sobre a interpretação do art. 859 daquele Código. A tese da presunção absoluta foi rechaçada: "essa presunção não é absoluta e indiscutível, constitui uma presunção iuris tantum (art. 859 [do CC/1916]) que poderá ser destruída por ação anulatória” (STF, RE 16.454, Rel. Min. Luis Gallotti, j. 03/04/1950).
} 
brasileiro isso seria impensável. O art. 1247, parágrafo único do Código Civil brasileiro de 2002 é expresso: "Cancelado o registro, poderá o proprietário reivindicar o imóvel, independentemente da boa-fé ou do título do terceiro adquirente".

O dispositivo legal afastava a boa-fé como fonte merecedora de proteção, ainda que o terceiro demonstre sua posição ética. Mesmo que o adquirente demonstrasse que a aquisição não era proveniente de terceiro, mas com causa no próprio título originário do alienante, que procura o cancelamento do registro, a proteção, em tese, estaria afastada. Percebe-se como o Código Civil brasileiro foi mais radical na proteção ao direito de propriedade do que em relação aos sistemas estrangeiros. E o mais surpreendente é que no direito brasileiro o registro de imóveis assume natureza constitutiva; contudo, esta constituição estaria assegurada, em um primeiro momento, apenas com transmissão oriunda do verus dominus (art. 1245 Código Civil brasileiro), e num segundo momento, ao adquirente por usucapião (art. 1242, parágrafo único, do Código Civil brasileiro).

Em outras palavras, ter-se-ia um sistema registral constitutivo que, na prática, se revelara declarativo quando se tratasse da tutela do terceiro de boa-fé. O sistema português, ao contrário, tem um sistema registral declarativo, mas que permitiria uma proteção excepcional ao terceito de boa-fé, o que na prática lhe confere natureza constitutiva (art. $5^{\circ}, n^{\circ} 1$ e $17^{\circ}$ n..$^{\circ} 4$ do Código Registral Predial português).

Todo este cenário muda com a redação do já citado art. 54, parágrafo único da Lei $\mathrm{n}^{\circ}$ 13.097/2015, cujo teor merece transcrição, com realce: “Não poderão ser opostas situações jurídicas não constantes da matrícula no Registro de Imóveis, inclusive para fins de evicção, ao terceiro de boa-fé que adquirir ou receber em garantia direitos reais sobre o imóvel, ressalvados o disposto nos arts. 129 e 130 da Lei $n^{0} 11.101$, de 9 de fevereiro de 2005, e as hipóteses de aquisição e extinção da propriedade que independam de registro de título de imóvel" (destacamos).

A leitura do texto não permite outra interpretação. $\mathrm{O}$ direito brasileiro vira uma nova página no capítulo dos direitos reais por meio desta importantíssima alteração que ainda não mereceu o tratamento adequado, uma vez que sua inserção, assistemática, no corpo da Lei $n^{\circ}$ 13.097/2015, não lhe confere o destaque merecido.

Pela nova lei, as situações jurídicas retratadas perante o registro de imóveis ganham proteção efetiva, mesmo existindo situação de evicção. Desse modo, se a propriedade não for transferida pelo titular do domínio e o terceiro estiver de boa-fé, existiria justa oposição à aplicação do art. 1247, parágrafo único, do Código Civil de 2002, o qual não encontra amparo perante a redação do art. 54, parágrafo único da Lei 13/097/2015. 
Os contornos para a construção da boa-fé subjetiva ética são mais simples no período atual. No direito brasileiro, a transmissão da propriedade imóvel acima de determinado valor (art. 108 Código Civil brasileiro) exigirá documento elaborado exclusivamente pelo notário e representado pela escritura pública (Lei no 7433/1985). Isto elimina, quase que por completo, a possibilidade de erro na transmissão. Note-se que o art. $1^{\circ}{ }^{\circ}, \S 2 .^{\circ}$ da Lei 7.433/1985 não mais se refere à exigência de apresentação de certidão de "feitos ajuizados" para a elaboração da escritura (a alteração decorreu também da Lei 13.097/2015). Isso reforça a necessidade de proteção ao terceiro de boa-fé que confia na publicidade e na fé pública registral. É correto afirmar que o direito brasileiro passa a contar com o princípio da proteção efetiva da fé pública. O terceiro não merecerá guarida apenas quando comprovada a má-fé, ou quando a lei afastar expressamente esta proteção, como na hipótese dos arts. 129 e 130 da Lei n 11.101/2005.

Na contraposição entre a aquisição a non domino e a usucapião, não há que se falar na proteção ao terceiro de boa-fé. A usucapião corresponde a uma solução forte do sistema e que visa a proteger a posse prolongada e não a posse instantânea. A usucapião se forma independentemente do registro e reside em modo originário de aquisição de propriedade que gera pretensão publiciana para o seu titular. Esta é a razão pela qual a parte final do art. 54, parágrafo único da Lei 13.097/2015, ressalva a proteção ao terceiro em relação às formas de aquisição e extinção da propriedade que não dependem do registro.

\section{A PROTEÇÃo a NON DOMino E A AQUisiÇÃo PELA USUCAPiÃo ABREVIADA DO CÓDIGO CIVIL BRASILEIRO}

O direito brasileiro não conhecia a aquisição tabular registral até a promulgação da Lei $\mathrm{n}^{\mathrm{o}}$ 13.097/2015. A solução encontrada pelo Direito brasileiro para a tutela do terceiro de boafé, até então, residia na figura especial da usucapião abreviada, nos termos do art. 1242, parágrafo único, do Código Civil: "Será de cinco anos o prazo previsto neste artigo se o imóvel houver sido adquirido, onerosamente, com base no registro constante do respectivo cartório, cancelada posteriormente, desde que os possuidores nele tiverem estabelecido a sua moradia, ou realizado investimentos de interesse social e econômico.”

A usucapião consiste em instituto milenar e retrata forma radical de extinção do direito de propriedade, pois os direitos reais não são vocacionados a serem atingidos por prescrição ou decadência. $\mathrm{O}$ direito de propriedade é perpétuo e somente se extingue pela destruição da res, 
pelo abandono, pela renúncia, pela alienação do direito por ato inter vivos ou transmissão causa mortis, pela desapropriação do poder público, ou pela usucapião.

A usucapião, também denominada prescrição aquisitiva, tem como objetivo a estabilidade e a paz social. Seu objetivo é diverso da proteção conferida ao terceiro de boa-fé que esta ligada à circulação econômica e proteção à segurança nas relações comerciais. A usucapião nasce pela inércia do proprietário e pelo interesse do possuidor que passa a conferir função social à propriedade abandonada. Há uma clara tendência de diminuição nos prazos de usucapião, mas o instituto ainda se torna inconfundível com a tutela do terceiro de boa-fé.

A figura do art. 1242, parágrafo único do Código Civil traz como requisitos essenciais: a) posse de boa-fé; b) lapso temporal de 5 anos; c) aquisição onerosa, d) registro do bem e e) exercício de posse qualificada por função social, fruição econômica, ou mesmo para a própria moradia. A leitura, en passant, dos referidos requisitos legais parece aproximar a figura da usucapião com a tutela conferida pelo art. 2652, nº 6 do Código Civil italiano. Todavia, como afirmado, as figuras são inconfundíveis. Como reconhece Mengoni, o direito italiano procurou a fonte deste dispositivo na aquisição tabular, por usucapião, do direito austríaco, conforme previsão dos $\S \S 61$ e ss. da lei dos livros fundiários de 25 de julho de $1871 .{ }^{28}$ Daí se explica o motivo de natural aproximação quando se estabelece uma comparação entre os institutos. Contudo, existe apenas uma semelhança aparente. A boa-fé consiste em requisito comum, bem como a necessidade da aquisição onerosa, do registro e do lapso temporal de 5 anos. Por outro lado, os institutos são diversos. A proteção a non domino é conferida ao terceiro que realiza a aquisição confiando no registro do titular que alienou o bem. Não existe uma aquisição da propriedade pelo exercício da posse baseada no registro efetuado pelo terceiro de boa-fé. Não é a posse mansa e pacífica que torna sua posição inatacável, mas o registro do título oriundo do dante causa, desde que ele permaneça, sem impugnação, nos 5 anos seguintes, mediante a comprovação da ausência de registro de qualquer demanda, que tenha como objetivo, a declaração de nulidade do negócio precedente que lhe fundamentou o nascimento. ${ }^{29}$

A figura do art. 2652, n. $6^{\circ}$ do Código Civil italiano representa um meio de exceção, pois toma como pressuposto a existência de uma ação de nulidade que tem como objetivo o cancelamento da inscrição primária. Na usucapião abreviada, o terceiro terá pretensão e exceção. Isso significa que poderá defender a sua posição em sede de contestação (Súmula 237

\footnotetext{
${ }^{28}$ Mengoni, Gli acquisti “a non domino”, p. 304.

29 "l'acquisto del terzo di buona fede diventa inattaccabile qualora dalla trascrizione del titolo (invalido) del dante causa sia trascorso un certo período di tempo (cinque anni) senza che sia trascritta la domanda direta a far dichiarare la nullità del negozio precedente" (Mengoni, Gli Acquisti a non domino, p. 305).
} 
do STF) ou exercer o direito de postulação pedindo a declaração da usucapião abreviada com efeito declaratório e retroativo.

Até a promulgação da Lei n. 13.097/2015, não existia no direito civil brasileiro - seja no Código Civil, ou mesmo na Lei de Registros Públicos - a possibilidade de proteção ao terceiro de boa-fé para a estabilização direito de propriedade pelo registro como meio de aquisição originário da propriedade. Esta proteção, na seara dos direitos reais, era limitada à usucapião quanto à tutela dos bens imóveis. Este anacronismo do direito brasileiro demonstra que a recepção da boa-fé pelo Código de 2002 foi tênue, muito embora ela possa ser percebida em outros pontos do Código Civil brasileiro.

A regra do nemo plus iuris e a proteção à aquisição a non domino não revelam situações díspares, quanto à proteção do objeto envolvido, pois ambas procuram tutelar o direito de propriedade, mas sob ângulos diversos. A regra do nemo plus iuris procura atender a um sistema estático de proteção ao titular do direito de propriedade, sendo um princípio básico comum a qualquer ordem jurídica, pois a sua existência confere estabilidade à ordem social. A proteção à aquisição a non domino nasce por via excepcional, como autêntica tutela ao terceiro de boafé. Os ordenamentos jurídicos construiram este instituto visando proteger a circulação dos bens. O Código Civil brasileiro tutelou a aquisição a non domino ${ }^{30} \mathrm{em}$ compartimento estanques, como se depreende do art. 161, relativo à fraude contra credores ${ }^{31}$ art. $167, \S 2^{\circ}$, na simulação; ${ }^{32}$ art. 879, parágrafo único, para o pagamento indevido; ${ }^{33}$ e art. 1817 , caput, na hipótese do herdeiro aparente. ${ }^{34} \mathrm{E}$ de modo surpreendente a orientação do direito brasileiro acabou sendo modificada radicalmente com a Lei $\mathrm{n}^{\circ}$ 13.097/2015, cujos reflexos ainda serão examinados pela doutrina e testados pela jurisprudência brasileira.

\footnotetext{
${ }^{30}$ Para um estudo completo sobre o tema e suas formas de aplicação no contexto do Código, Francisco Landim, $A$ Propriedade Imóvel na Teoria da Aparência, especialmente pp. 173-238.

31 “A ação, nos casos dos arts. 158 e 159, poderá ser intentada contra o devedor insolvente, a pessoa que com ele celebrou a estipulação considerada fraudulenta, ou terceiros adquirentes que hajam procedido de má-fé" (destacamos).

32 "§ $2^{\circ}$ - Ressalvam-se os direitos de terceiros de boa-fé em face dos contraentes do negócio jurídico simulado".

33 "Se aquele que indevidamente recebeu um imóvel o tiver alienado em boa-fé, por título oneroso, responde somente pela quantia recebida; mas, se agiu de má-fé, além do valor do imóvel, responde por perdas e danos. Parágrafo único. Se o imóvel foi alienado por título gratuito, ou se, alienado por título oneroso, o terceiro adquirente agiu de má-fé, cabe ao que pagou por erro o direito de reivindicação".

34 “São válidas as alienações onerosas de bens hereditários a terceiros de boa-fé, e os atos de administração legalmente praticados pelo herdeiro, antes da sentença de exclusão; mas aos herdeiros subsiste, quando prejudicados, o direito de demandar-lhe perdas e danos" (destacamos). Sobre o herdeiro aparente vide o importante estudo de Alberto Montel, Sul Concetto de Erede Apparente di Buona Fede, pp. 06-15.
} 


\section{REFERÊNCIAS}

ARAÚJO, Fabio Caldas de. Usucapião. 3. ed. São Paulo, Malheiros, 2015. Intervenção de Terceiros. São Paulo, Malheiros, 2015.

BIANCA, C. Massimo. Diritto Civile (La Proprietà),v. VI. Milano: Dott. A. Giuffrè, 1999. CARVALHO, Afrânio. Registro de Imóveis. Rio de Janeiro: Forense, 1982.

CAVALCANTI, José Paulo, “A Falsa Posse Indireta”. edição fac-símile. Recife, 1990.

CHARLES, Sébastian, e LIPOVTESKY, Giles. Tempos Hipermodernos. Edições 70, 2011.

FENET, P. A. Recueil Complet des Travaux Préparatoires du Code Civil, t. XIII, reimpression de 1827. Osnabruck: Otto Zeller, 1968.

GAMA, Affonso Dionysio. Os Registros Publicos do Código Civil (Lei no 4827 de 7 de fevereiro de 1924 e Reg. 18542 de 24 de dezembro de 1928),

GIL, Antonio Hernandes. La Funcion Social de la Posesion. Madrid: Alianza Editorial, 1969. GLITZ, Frederico Eduardo Zenedin; ROCHA, Glenyo Cristiano. QUEBRA ANTECIPADA DO CONTRATO: UMA ANÁLISE DE DIREITO COMPARADO. Revista Juridica, [S.l.], v. 1, n. 46, p. 300-333, jul. 2017. ISSN 2316-753X. Disponível em: <http://revista.unicuritiba.edu.br/index.php/RevJur/article/view/2010/1291>. Acesso em: 23 abr. 2020. doi:http://dx.doi.org/10.21902/revistajur.2316-753X.v1i46.2010. HUC, Commentaire Théorique \& Pratique du Code Civil, t. XIV. Paris: P. Pichon, 1903.

Memórias de Litteratura Portugueza Publicadas pela Academia Real das Sciências de Lisboa. t. I. Lisboa: Officina da mesma Academia, 1792.

KERN, Marinho Debinski Kern, A lei 13.097/2015 adotou o princípio da fé pública registral? v. 78 RT, 2015.

MENEZES CORDEIRO, António Manuel da Rocha. Da Boa Fé no Direito Civil. 2a reimpressão. Lisboa: Almedina, 2001.

O Levantamento da Personalidade Colectiva No Direito Civil e Comercial. Coimbra,

Livraria Almedina, 2000.

MENGONI, Luigi. Gli Acquisto A Non Domino, Roma: Giuffrè, 1968.

Direitos Reais. Lisboa: Lex- Edições Jurídicas, 1993.

MEYER, Rudolf. Bona fides und lex mercatoria in der europäischen Rechtstradition. Band V.

Göttingen: Walistein Verlag Göttingen, 1994.

NETO, Soriano. Publicidade Material do Registro Imobiliário (Efeitos da Transcripção).Recife, 1940.

PONTES DE MIRANDA, Francisco Cavalcanti. Tratado de Direito Privado. (parte especial), t. X. $4^{\text {a }}$ ed. São Paulo: RT, 1983. 
Repertório das Ordenações e Leis do Reino de Portugal. t. III. Coimbra: Real Imprensa da Universidade, 1795.

WEIRICH, Hans-Armin. Grundstüksrecht. Verlag C.H. München, 2006. 